\title{
THE ELECTORAL COLLEGE: OLD REFORMS TAKE ON A NEW LOOK
}

\author{
Estes KefaUVER*
}

\section{INTRODUCTION}

Past efforts at electoral college reform have produced little more than sympathetic amusement among hard-nosed realists of politics and government. It was bad enough to advocate a remedy which required a two-thirds vote of the Congress and ratification by three-fourths of the states. But, in addition, we so-called reformers were divided among three or four different remedies. Some who supported one form of change preferred the status quo to all others. The existing system was imperfect to enough people but for too many different reasons.

I962 may be the year of the big break-through. Baker v. Carr ${ }^{1}$ may be the most significant development for electoral college reform in many years because it eliminates the chief current defense of our present system. Opponents of reform have generally admitted the unfairness of awarding a state's entire electoral vote to the winner of a bare plurality of its popular vote. They conceded that the state unitrule disfranchises minority party voters in each state, risks a minority President, and inflates the power of large states and urban interests within those states. But then they pointed to the beam in the reformer's eye-the make-up of state legislatures and the House of Representatives to the prejudice of urban interests. If this was a valid argument before Baker $v$. Carr, the same considerations should now lead to the opposite conclusion. As urban interests gain their proportionate voice in state legislatures, they should be more willing to give up their favored position in presidential elections.

Establishing the need for change is now the easiest part of the reformer's task, but Baker v. Carr does not help choose the form which change should take. It is now more important than ever to take a close hard look at the proposed reforms and to consider carefully what the effects of each would be.

\section{The Present System}

The I960 Kennedy-Nixon election dramatically demonstrated some of the defects of our constitutional method of electing the President. As the electoral college lumbered like an oxcart through the selection of America's President for the space age, its machinations sounded several alarms. I do not refer to the razor-thin margin. The possibility of close elections will always be with us and in a federation of 185

\footnotetext{
- United States Senator from Tennessee. Chairman, Senate Subcommittce on Constitutional Amendments. I962.

${ }_{3} 69$ U.S. 186 (1962). This, of course, is the famous Tennessee apportionment decision of March 26,
} 
million people spread from Maine to Hawaii, uncertainty and suspense will attend the final determination of a close contest under any system.

A collection of happenings throughout this crazy quilt system should have aroused us all to the need for change. ${ }^{2}$ In Oklahoma, Mr. Henry D. Irwin, a regular Republican elector who was expected to vote for Nixon, voted instead in the electoral college for Senator Harry F. Byrd, who, despite his merits otherwise, was not a candidate for the Presidency. Fourteen electors in Mississippi and Alabama also recorded votes for Senator Byrd. Unlike their Oklahoma counterpart, they had campaigned as unpledged electors and at least had some sort of mandate to exercise their own judgment. Louisiana's school segregation crisis produced an unsuccessful movement in its Legislature to suspend the state's election laws after Kennedy had won on November 8 so that unpledged electors could then be appointed. In Illinois, charges of election irregularities were accompanied by a threat that the state's Republican Election Board might refuse to certify the twenty-seven electoral votes cast by Democratic electors. An opposite result materialized in Hawaii where the votes of both Democratic and Republican electors were certified to Congress.

A divided ticket of Democratic electors in Alabama baffled election statisticians and demonstrated the myth of our so-called "popular vote." Voters who pulled the party lever for the Democratic ticket elected six unpledged electors who voted in December for Senator Byrd and five regular Democratic electors who voted for President Kennedy. Attempts to translate this into popular vote totals deserve passing mention because they expose the inherent fiction of the popular vote concept.

Customarily, a candidate is awarded the popular vote figure received by the highest elector on his ticket. The six unpledged Alabama electors each received from 322,000 to 324,000 popular votes and the Kennedy electors received about 3I7,000 to 3r8,000 votes. The eleven Republican electors each drew 237,98I votes. Obviously, the latter group intended to register their preference for Mr. Nixon. But what of the 324,050 Alabamans who voted in varying combinations for Democratic electors? Most of them voted for the entire slate and thus were voting at the same time both for and against Mr. Kennedy. The Clerk of the House of Representatives in compiling his official statistics ignored the ticket split and merely listed the Democratic popular vote at 324,050. If the votes for Byrd were similarly treated, Alabama Democrats obviously would be recorded twice and the total Alabama vote would be correspondingly inflated. The Congressional Quarterly distributed 5/II of the total Democratic vote to Kennedy and 6/II to unpledged. This avoids duplication but it determines the popular vote from the electoral vote which is at odds with our basic assumption. Also, it leads to a hypothetical popular vote victory in Alabama (and the nation) for Mr. Nixon, a fact never claimed by the most zealous of his supporters.

\footnotetext{
${ }^{2}$ The incidents set forth in the next few paragraphs of the text are discussed and documented in a Library of Congress study, Operation of the Electoral System in Selected States in 1960, which is printed in Hearings Before the Subcommittee on Constitutional Amendments 'of the Senate Committee on the Judiciary on Nomination and Election of the President and Vice President, 87th Cong., Ist Sess. 4 I2 (I96I).
} 
The only conclusion which can be drawn is that there is a great gulf between our presidential election system as it is popularly viewed and as it actually exists. Gymnastics with the Alabama vote serve no purpose in attempting to measure the popularity of either candidate. Other features of the system prevent it from being accurate in this respect. But a realistic look at this and other peculiarities of our system would be useful if it drives home to the American people the myths under which they enthusiastically flock to the polls and exercise their democratic birthright every fourth November.

A renewed demand for electoral reform followed the 1960 election in at least one sense. Those of us in Congress who have worked for reform for years hopefully renewed our efforts. There was an increase in the number of proposed constitutional amendments to the Constitution introduced in the Eighty-seventh Congress, but after presiding over extensive hearings last year as Chairman of the Subcommittee on Constitutional Amendments, I am still waiting for evidence of substantially increased support for reform at the grass roots level.

Analysis of constitutional reforms should proceed from a realistic restatement of the constitutional foundation upon which presidential elections now rest. Unfortunately, much public discussion of the subject proceeds upon assumptions without basis in the Constitution.

The present system is embodied in article two, section one, and the twelfth amendment to the Constitution, which provide simply that the President and Vice President shall be chosen by electors appointed by each state in the manner directed by its legislature. Each state has a number of electors equal to the total of its senators and representatives. ${ }^{3}$ The electors are to meet in their respective states and ballot separately for the President and Vice President, at least one of whom shall not be an inhabitant of their state. A signed list showing their votes is certified and transmitted to the seat of the United States Government directed to the President of the Senate.

The votes are counted in the presence of the Senate and House of Representatives. A majority of the votes of the whole number of electors appointed is necessary for election. Absent a majority, the House of Representatives elects the President from the three candidates receiving the largest number of votes. In such an election, each state casts but a single vote, with a majority of the state's congressional delegation thus controlling the vote of the state. A majority of votes is necessary to elect, and in the absence of such majority the Vice President acts as President. In the absence of a majority of vice presidential electoral votes, the Senate elects the Vice President from the two highest candidates by simple majority vote.

The two-party system has produced an extra-constitutional elective process which is virtually uniform throughout the states, with the result that few Americans are aware of the meager nature of this constitutional scheme and the limited extent of

\footnotetext{
${ }^{3}$ The twenty-third amendment now gives the District of Columbia the number of electors to which it would be entitled if it were a state, but in no event more than the least populous state.
} 
their constitutional rights in the election of their President. Several popular misconceptions are apparent to the most casual student.

First, the people of the United States do not elect the President in the November election. ${ }^{4} \mathrm{He}$ is elected by $53^{8}$ individual electors ${ }^{5}$ meeting in fifty states and the District of Columbia on the first Monday after the second Wednesday in December. ${ }^{6}$ For the past eighty-five years, each state has appointed its electors by popular vote but this continues only at the sufferance of state legislatures and not as a matter of right."

Most people view the elector merely as a quaint procedural device for registering the will of the people. The fidelity of electors over the years has largely justified this faith but this assumption is also without legal basis.

Alexander Hamilton wrote that the electoral college system was intended to insure that the election of the Chief Executive "should be made by men most capable of analyzing the qualities adapted to the station, and acting under circumstances favorable to deliberation, and to a judicious combination of all the reasons and inducements which were proper to govern their choice." With characteristic distrust of the popular will, he added: "A small number of persons selected by their fellow citizens from the general mass will be most likely to possess the information and discernment requisite to such complicated investigation." ${ }^{\text {" }}$

Hamilton's aspirations for the electors as a deliberative body were soon frustrated by the advent of the two-party system and the rise of popular democracy. Extraconstitutional devices such as pledges, statutory instructions and the short ballot have largely guaranteed elector fidelity but there is little doubt that each elector is still constitutionally free to vote for whomever he chooses in December, regardless of the manner in which he was "appointed" in November.

\footnotetext{
"The Tuesday next after the first Monday in November is set by Congress as the date when “. . . electors ... shall be appointed." 3 U.S.C. $\$$ I (1958). Section I of article II of the Constitution authorizes Congress to determine ". . . the Time of choosing the Electors, and the Day on which they shall give their Votes; which Day shall be the same throughout the United States."

This will be the electoral vote total in 1964 . In 1960 there were 537 electoral votes because of two temporary members of the House of Representatives added upon the admission of Alaska and Hawaii to statehood: In I964, three new electoral votes will be cast by the District of Columbia as a result of the twenty-third amendment, but the House membership will revert to 435, unless it is increased by Congress, which appears unlikely.

"The date set by Congress when electors shall meet "at such place in each State as the legislature of such State shall direct." 3 U.S.C. $\$ 7$ (1958).

${ }^{7}$ No state legislature has exercised its right to appoint electors itself since South Carolina abandoned the practice in 1860 , except for the newly-admitted state of Colorado in 1868 and the reconstructed state of Florida in 1876 . Prior to 1828 , most states did so at one time or another. Hearings, supra note 2 , at 785 .

8 The Federalist No. 68, at 424 (Lodge ed. i 888) (Hamilton).

${ }^{\circ}$ Wilkinson, The Electoral Process and the Power of the States, 47 A.B.A.J. $25 \mathrm{I}$ (I96I). In holding that Alabama could require a pledge of a candidate for elector as a condition of his being placed on the ballot in a primary election, the Supreme Court expressly left unanswered an argument that such pledges would be enforceable if violated because of the elector's constitutional freedom to vote as he chooses in the electoral college. Ray v. Blair, 343 U.S. 213 (1951). A lower court in New York indicated by dictum that an elector could be compelled by mandamus to vote in accordance with his pledge. Thomas v. Cohen, $x_{4} 6$ Misc. 836,262 N.Y. Supp. 320 (Sup. Ct. x933), but the courts of Alabama and Ohio have indicated to the contrary. Opinion of the Justices No. 87, 250 Ala. 399, 34 So.2d 598 (x948);
} 
The most controversial feature of our present system is, of course, the so-called unit-rule or general-ticket method by which all of a state's electoral votes are cast in bloc for the candidate receiving a plurality of its popular votes. Like popular voting for electors and binding by pledge, this, too, is extra-constitutional. It results from our two-party system but is solely the product of state legislation. The plenary power of state legislatures resulted in a variety of methods other than election by state-wide general ticket in our early history. In addition to direct legislative appointment, electors were also chosen by the people voting in districts fixed by the legislature or by a combination of electors chosen by districts and electors chosen at large. In 1796 and 1800 , the Tennessee legislature divided the state into three districts and designated three named individuals in each district to appoint electors.

We do not have to go back far to find a state legislature manipulating its system for partisan advantage in a particular election. In 1892, the Michigan legislature adopted a district system for the purpose of splitting the state's electoral votes in the coming presidential election. The Supreme Court of the United States upheld the legislature's power and quoted with approval the following statement which had been made in 1874 by a Senate Committee: ${ }^{10}$

The appointment of these electors is thus placed absolutely and wholly with the legislatures of the several states. They may be chosen by the legislature, or the legislature may provide that they shall be elected by the people of the state at large, or in districts, as are Members of Congress, which was the case formerly in many states; and it is, no doubt, competent for the legislature to authorize the Governor, or the supreme court of the state, or any other agent of its will, to appoint these electors. This power is conferred upon the legislatures of the states by the Constitution of the United States, and cannot be taken from them or modified by their state constitutions any more than can their power to elect Senators of the United States. Whatever provisions may be made by statute, or by the state constitution, to choose electors by the people, there is no doubt of the right of the legislature to resume the power at any time, for it can neither be taken away nor abdicated.

The system produces two sorts of objections-pragmatic and philosophical. Pragmatic objections are concerned with the mechanics of the system's operation and are addressed primarily to the retention of the office of presidential elector, the method of resolving the election when no candidate obtains a majority of electoral votes, and the potential for manipulation of the system from state to state and from election to election. Philosophical objections are addressed to the fact that our system does not insure that the President is the candidate preferred by the largest number of Americans and to the distribution of political power under the present system, as between large and small states or as between rural and urban citizens.

\footnotetext{
State v. Hummel, 150 Ohio St. 127,80 N.E.2d 899 (1948). In the latter case, the Ohio court stated: "Ohio is entitled to 25 presidential electors to be elected at the 1948 general election. Each one of the 25 elected may vote as he pleases for any person eligible for the office of President or Vice President of the United States. It is only by force of a moral obligation, not a legal one, that the presidential electors pledged to certain candidacies fulfill their pledges after election." I50 Ohio St. at 246,80 N.E.2d at 909 .

${ }^{10}$ McPherson v. Blacker," ${ }_{4} 6$ U.S. $x, 34$ (1892).
} 
It is safe to say that the pragmatic objections are a concern of all proponents of change. The uncertainties and dangers inherent in the present system have no vocal defenders although there is disagreement as to whether these defects alone merit correction by constitutional amendment.

The philosophical and political aspects of the problem result from two elements of the present system: the weighted electoral votes of the states and the operation of the state unit-rule method of casting those votes. At this point we reach the principal points of division among those who advocate substantial reform. Shall the states' electoral votes be retained at all? If so, what is to be substituted for the unit-rule method?

This may be somewhat of an oversimplification but it is a worthwhile basis for approaching the three principal proposals-direct national election, the district system, and the proportional system. Direct election eliminates the weighted electoral votes of the states. The district and proportional plans retain the electoral votes but differ significantly in their method and extent of eliminating the unit rule.

\section{Direct National Election}

When this method was proposed in the original Constitutional Convention, it was defeated by a vote of nine states to two. It has fared little better in Congress in the intervening years, although as early as 1826 a constitutional amendment for direct national election was introduced by Representative McManus of New York. In I950, when the Senate approved the proportional system, Senator Langer of North Dakota offered as a substitute direct popular election along with national nominating primaries. The Langer substitute was rejected by a vote of 60 to $3^{1}$. Senator Humphrey of Minnesota then offered as a substitute an amendment which provided only for election by direct national vote and it was defeated by a vote of $6_{3}$ to 28 . In 1956 , when the Senate considered the proportional-district system compromise, Senator Langer again offered an amendment for nomination and election by national popular vote. This time it was defeated 69 to 13 . Senator Lehman of New York then offered an amendment providing only for election by national popular vote and this was rejected by 66 to I7.

The chief advantage of this proposal is obvious; it would completely eliminate the possibility of a so-called "minority President," which cannot honestly be claimed for any other proposal. This term sometimes refers to a President who is elected without a majority of the popular vote although with more popular votes than any opponent. This has happened in fourteen elections. It is used more frequently to refer to a President who is elected with fewer popular votes than his leading opponent. This has happened three times. In 1824, although Andrew Jackson received more popular and electoral votes than did John Quincy Adams, the latter was elected by the House of Representatives. In 1876 , although Samuel J. Tilden polled 247,448 votes more than Rutherford B. Hayes, the resolution of contested slates of electors by the Electoral Commission created by Congress resulted in Hayes being 
elected by one electoral vote. In I888, although Benjamin Harrison received 90,728 fewer popular votes than did Grover Cleveland, Harrison was elected by 233 electoral votes to Cleveland's 168 . We have had several "near-misses" where shifts of handfuls of popular votes in a few states would have produced a minority President. ${ }^{11}$ - This feature of the present system probably draws the most fire and arouses the most emotional objections. Yet a poll which I conducted last year of heads of the nation's political science departments showed only 34.2 per cent in favor of direct election. How do we account for the relative unattractiveness to political scientists of this simple straightforward reform which would place presidential elections under the purest democratic principle? By eliminating the state as an electoral counting unit every vote would be equally reflected in the national totals. The minority party in a state would not see its votes counted out at the state level as is now done by the unit-rule's operation. The "swing votes" of minority blocs in pivotal states would lose the special importance they now enjoy by virtue of their power to tip the electoral vote into one column or another in a close vote. The votes of any given group of Americans would look to a candidate like those of any other group.

Despite the objections to a minority President, there apparently is still a strong feeling that the federal principle should not yet be abandoned in presidential elections. State and regional interests are still sufficiently important that sheer numbers of votes on a national level should not determine the Presidency. Disproportionate weighting of the votes of citizens of less populated states may become increasingly distasteful as the Supreme Court's decision on representation in state legislatures is implemented; $;^{12}$ but for the time being the consensus is against a system which would ignore state lines and interests and cause campaigns to be directed to masses of voters.

A related objection is that direct election would necessarily nationalize our election machinery. Every voter would have an immediate interest in the fairness and accuracy of the election machinery in every state. Voters in Maine, for instance, could see their votes nullified by opposing votes in Alaska as readily as by votes cast in the same precinct in Maine. That this would require national election laws

${ }^{11}$ In 1916 Woodrow Wilson won re-election with a nationwide popular plurality of more than 590,000 votes over Charles Evans Hughes. Yet Hughes would have been elected if he had carried California, a state which he lost by only 3,806 votes. In the election of 1884 , Grover Cleveland had a 23,000 vote plurality over James G. Blaine. The election turned on the outcome in the state of New York, which Cleveland won by only 1,148 votes. In 1844 , Polk defeated Clay by I70 electoral votes to 105 and by a popular vote margin of 38,000 votes. A switch of 3,000 votes in the state of New York would have changed the result and elected Clay. In 1948, a shift of 17,000 votes in Illinois, 3,500 votes in Ohio, and 9,000 votes in California would have transferred seventy-eight electoral votes from Mr. Truman to Mr. Dewey, and the latter would have been elected despite the fact that his opponent had polled two million more popular votes.

${ }^{22}$ A hint to possible new sources of electoral college dissatisfaction is in the opinion of the three-judge federal court which has held the Georgia county unit system unconstitutional. The Netv York Times quotes the court's opinion as going on to say that no new county unit system would be unconstitutionally discriminatory ". . . if the disparity against any county is not in excess of the disparity that exists against any state in the most recent electoral college allocation. . .." N.Y. Times, April 29, 1962, $\$ 1$, p. 1, col. 6 , at p. 54 , col. 5. The table on page 195 infra shows this disparity to be more than 5 to 1 -one electoral vote for 75,389 persnns in Alaska against one vote for 302,930 persons in California. 
and federal administration of elections is not denied by. most advocates of direct national election.

A weaker argument is that direct election would result in a race among the states to lower voting qualifications as each state sought the greatest possible voice in selecting the President. Some suggest that ridiculous voting ages might result and that all states would be driven to the lowest common denominator of voting qualifications. This could be avoided by providing in any amendment that voting qualifications in each state shall be those requisite for electing the most numerous branch of the state legislature, as is the case now for congressional elections. In order to generate a larger popular vote in presidential elections, a state would then have to adopt the same broadened suffrage requirement for electing its state legislators, senators, and representatives.

The most frequent argument made against direct national election in the Congress is that it would be futile for Congress to submit such an amendment to the states; that it would have no chance of ratification by three-fourths of the states because thirty-six of them have added weight in the election of the President by reason of the electoral college system. This theoretical advantage of voters in smaller states is shown by the following table:

\begin{tabular}{|c|c|c|c|}
\hline Rank and State & Ratio & Rank and State & Ratio \\
\hline \multirow{15}{*}{ 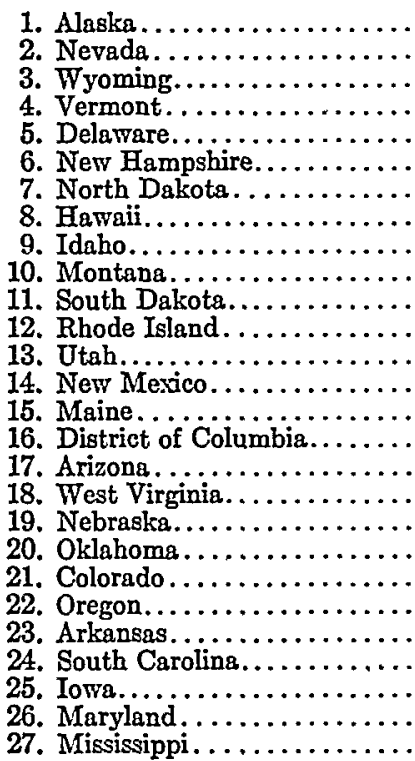 } & \multirow{15}{*}{$\begin{array}{r}75,389 \\
95,093 \\
110,022 \\
129,960 \\
148,764 \\
151,730 \\
158,112 \\
158,193 \\
166,798 \\
168,692 \\
170,129 \\
214,872 \\
222,657 \\
237,756 \\
242,316 \\
254,652 \\
260,452 \\
265,774 \\
282,266 \\
291,036 \\
292,325 \\
294,781 \\
297,712 \\
297,824 \\
306,369 \\
310,069 \\
311,163\end{array}$} & 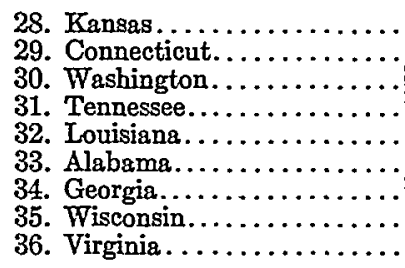 & $\begin{array}{l}311,230 \\
316,904 \\
317,024 \\
324,281 \\
325,702 \\
326,674 \\
328,593 \\
329,315 \\
330,579\end{array}$ \\
\hline & & National average.... & 333,314 \\
\hline & & 37. Kentucky........... & 337,573 \\
\hline & & 38. Minnesota.......... & 341,386 \\
\hline & & 39. North Carolina...... & 350,473 \\
\hline & & 40. Florida.$\ldots \ldots \ldots \ldots \ldots$ & $\begin{array}{l}353,682 \\
356,870\end{array}$ \\
\hline & & 42. Indiana............. & 358,654 \\
\hline & & 43. Missouri............. & 359,98 \\
\hline & & 44. Massachusetts.... & 359,984 \\
\hline & & 45. Michigan........ & 372,533 \\
\hline & & 46. Ohio............ & 373,325 \\
\hline & & 47. Texas. . . . $\ldots \ldots$ & 383,187 \\
\hline & & 48. Illinois. . $\ldots \ldots \ldots \ldots \ldots \ldots$ & 387,736 \\
\hline & & 50. Pennsylvania...... & 390,32 \\
\hline & & 51. California....... & 392,930 \\
\hline
\end{tabular}

Yet can it truthfully be said that a voter in Alaska has five times the voice in electing the President as that of the voter in California or that a Nevadan has four times the voice of a New Yorker? The opposite is nearer the truth because New 
York equals fifteen Nevadas where it really counts-in the electoral vote column as state units.

There were instances in our hearings where a witness would dismiss the practical chances of direct national election proposals as depriving the small states of their electoral vote advantage and then attack the present system as favoring the large states over the smaller ones.

The truth is that we have swung full circle and a system originally designed to favor the small states is now achieving the opposite result. This fact led former Presidents Truman and Hoover to sound similar notes in statements made for our hearings. President Truman described our problem as "the emergence of the big cities into political overbalance, with the threat of imposing their choices on the rest of the country." Mr. Hoover noted that our inquiry "confronts the same difficulties as were met by the Founding Fathers-that is, to prevent domination by a few large states."

If hope is ever abandoned for other reforms and we are faced with a choice between direct national election and the present system, this proposal might take on a different light. But for the present and the foreseeable future, I do not feel that direct national election is a serious possibility as a practical matter. It conflicts too greatly with our federal principles and some deep-seated facts of political life.

\section{The District System}

Both the district and proportional plans are aimed principally at the unit rule, the former by dividing electoral votes among districts within each state and the latter by proportioning electoral votes in each state in accordance with its popular vote.

Some form of the district system of choosing presidential electors was employed by a number of states in the early history of the nation. It was favored in some form by such early statesmen as James Madison, Thomas Jefferson, John Quincy Adams, Thomas Hart Benton, Andrew Jackson, Martin Van Buren, and Daniel Webster. Madison wrote in 1823 that it "was mostly, if not exclusively, in view when the Constitution was framed and adopted." Four times between $18 \mathrm{r}_{3}$ and 1824 , constitutional amendments containing some form of the district system were approved by the Senate. In 1820 , the House approved a district plan by a vote of 92 to 54 . None has since been brought to a vote in either House.

Until the Eighty-seventh Congress, recent proposals of the district system provided that two electors corresponding to senators from each state would be elected at large and the balance (those corresponding to representatives) would be chosen by congressional districts. This form of the district system became known as the Mundt-Coudert plan. The current version sponsored by Senator Mundt differs in that it calls for independent presidential elector districts instead of using congressional districts.

Since the principal objective of the district system is to alleviate the consequences of the unit-rule or general-ticket system, it is relevant to consider the extent to which 
it will split state units of electoral votes. Historically, the district system had limited results in breaking up state unit votes. From 1789 to 1892 , there were fifty-two instances of states using some form of district system. In thirty-six instances, the state's vote were still cast as a unit. ${ }^{13}$ Analysis of how the district system would have operated in 1960 indicates that a surprisingly high number of states' votes would have still been cast in bloc. If congressional districts had been used for a district plan in I960, electoral votes would still have been cast in a bloc by these twenty-one states: Alaska, Arizona, Delaware, Georgia, Hawaii, Iowa, Kansas, Louisiana, Maine, Massachusetts, Nebraska, Nevada, New Hampshire, New Mexico, North Dakota, Oregon, Rhode Island, South Dakota, Utah, Vermont, and Wyoming. These states had a total of IIg electoral votes. In an additional seven states with a total of fifty-one electoral votes, only one vote in each would have been split from the state unit. They are Arkansas (I of 8), Colorado (I of 6), Connecticut (I of 8), Idaho ( $\mathrm{I}$ of 4 ), Indiana ( $\mathrm{I}$ of $\mathrm{I}_{3}$ ), Montana ( $\mathrm{I}$ of 4 ), and Oklahoma ( $\mathrm{I}$ of 8 ). In six more states having a total of seventy-five electoral votes, the minority party would have captured no more than twenty-five per cent of the electoral vote. They are Kentucky (2 of ro), Ohio ( 5 of 25), South Carolina (2 of 8), Virginia (3 of I2), West Virginia (2 of 8), and Wisconsin (3 of 12$)$. $^{14}$

This suggests that in many states, the division of political sentiment is sufficiently uniform throughout the state that voting by districts will produce the same result as voting by states. For the minority party to capture electoral votes, its strength must be localized in pockets large enough to carry districts. In many states (and all districts), minority party voters would still be "disfranchised" in the sense that their popular votes would not be reflected in the national vote totals.

In populous states with distinctive rural and urban areas, the district system very effectively splits state unit votes. Using the same analysis, in $1960 \mathrm{New}$ York's vote would have split 25-20, California I9-I3, Illinois I5-I2, Pennsylvania I7-I5, and Michigan ro-ro. ${ }^{15}$ The large states would be drastically affected while most small states and essentially one-party states would see little change in the course of their electoral votes. One can see the truth to Thomas Hart Benton's I834 prediction that "the district system would break the force of the large states."16

In still another way, the district system's impact would vary between large and small states. This is in the weight of individual votes where the district system is claimed to correct disparities favoring large states. Under the unit-rule system each citizen has as many votes in presidential elections as his state has electors. A New Yorker voted in Ig60 for all of his state's forty-five electors, but the Nevadan only voted for three. The district system is said to be an equalizer, limiting every person to voting for only three electors.

At first glance, this may appear valid but it ignores another vitally important

${ }^{18}$ Hearings, supra note 2, at 508 .

1t Id. at 4IY. (The first list obviously includes six states having only three electoral votes which would not be districted.)

${ }^{38}$ Ibid.

10 $1 d$. at $8 \mathrm{r} 3$. 
factor-the number of voters sharing the choice in each instance. There is no equality if one set of three electors is elected by a group of 100,000 voters and three other electors are chosen by $1,000,000$ voters. When the citizen of New York voted for his forty-five electors in 1960 , he shared his choice with more than 7,200,000 other voters. In I960, each electoral vote of New York corresponded to 162,018 popular votes, but in Nevada to only 35,756 voters. The district system would aggravate these state-to-state disparities. The one elector chosen corresponding to each voter's representative in Congress will roughly represent the same number of persons in every state. But the disparity in voters per elector is widened greatly for the two at-large senatorial electors who represent two-thirds of each voter's participation. In I960, more than 7,200,000 New York voters would have shared in selecting the at-large electors under a district system, as against approximately 60,000 voters in Alaska-a ratio of 120 to $r$, worse than the extremes of Georgia's much publicized county unit system.

Instead of equalizing voter representation, the district system therefore introduces a new inequality of voting weight in favor of smaller states' citizens far greater than that now operating against them. This demonstrates the fallacy of attempting to apply concepts of voter equality while retaining the system of electoral votes which flows from federal principles of state representation in our bicameral national legislature.

Another problem raised by the district system is the vast decentralization which it would introduce into presidential elections. Assuming the membership of the House is not increased, there will be 435 separate and independent single-elector districts and each state continues to be a district for choosing two at-large electors. In the District of Columbia and five states having only one representative, there will be no districting because the single-elector district corresponds with the twoelector district. Each will be a three-elector district. Within the forty-five states having more than one representative there will be created 430 single-elector districts corresponding to the representatives from these states. Thus, viewing a "district" as a distinct geographical area to which electoral votes are assigned as a unit, there will be six three-elector districts, forty-five two-elector districts, and 430 single-elector districts, or a total of $48 \mathrm{r}$ separate presidential election districts. The $53^{8}$ electoral votes which would otherwise be cast in fifty-one state units of from three to fortythree votes will be scattered among 48I units of from one to three votes each. This fragmentation of a federal election carries obvious implications in terms of targeting campaign appeals, reporting election returns, contesting state and district results, and speedy ascertainment of the national results.

More troublesome than the plethora of $48 \mathrm{x}$ electoral districts is the possibility of manipulation and political abuses of the 430 districts which will be established by state legislatures. Prior to the Eighty-seventh Congress, proposals of the district system provided thàt electoral districts would be identical with congressional districts, If a state elected its congressmen at large, it would also choose its presidential electors 
at large. If congressional districts were gerrymandered or malapportioned for the benefit of a particular party in power, their effects would have been carried over into the election of the President. ${ }^{17}$

In reintroducing this proposal in the Eighty-seventh Congress, its principal sponsors admitted that the past proposal (the Mundt-Coudert plan) was vulnerable on this point. It was therefore modified to require that electoral districts be of "contiguous and compact territory" and contain "as nearly as practicable the number of persons entitling the state to one Representative in the Congress." 18

This envisions either two state systems of federal electoral districts, one for congressmen and one for presidential electors, or that congressional districts will be re-constituted to meet these standards. There seems to be general agreement that although two sets of electoral districts are possible, they would not be desirable. Voters at the same polling place could be voting for the same congressmen but for different district presidential electors, or vice versa. (Elimination of the elector could cure this but still the district presidential vote could be included in a different district's returns.)

Instead of either reforming congressional districts or establishing separate presidential districts, state legislatures would be tempted to adopt existing congressional districts as their presidential elector districts. Many of the same political pressures and chances for partisan advantage would operate in both instances. In fact, it is possible for either type of district to meet the tests of compactness, contiguity and equality of population and still be drawn for political advantage. A common sort of example is the Kansas congressional redistricting after the 1960 census. The Republican state legislature split Democratic Kansas City between two rural strongly Republican districts. Neither party has a monopoly on this sort of thing but densely populated metropolitan areas are obviously more vulnerable to this divide-andconquer partitioning.

The next question is whether the constitutional standards for presidential elector districts can be enforced as a practical matter. The Supreme Court's decision in the Tennessee apportionment case indicates that federal courts will no longer avoid the "political thicket" of districting and apportionment. In any event, the constitutional amendment could include a clause requiring the courts to take jurisdiction and enforce districting standards. Nonetheless, the suitability and practicality of judicial action in this area still raises many questions. What would be the allowable deviation of norms of population? Would the courts establish proper districts or merely enjoin certification of election results from improper districts? Would the state's two at-large electoral votes be validly cast in all events? Presumably, a court could not order an at-large election because the Constitution would specifically

\footnotetext{
${ }^{17}$ Disparities in population of congressional districts may account for how the 1960 election results would have been changed by this system. According to an analysis by the Congressional Quarterly, Feb. 13, 1961, a district system using congressional districts would have caused Nixon to defeat Kennedy by thirty-three electoral yotes, 278 to 245 . Hearings, supra note 2 , at 411 .

${ }^{18}$ S.J. Res. 12, 87th Cong., Ist Sess. (Ig6r).
} 
require that electors be chosen by districts. How would the cumbersomeness and delay of appeals affect elections?

An alternative method for enforcing district standards might be the power of Congress in counting the electoral votes to reject votes certified from states whose districts did not conform to constitutional standards. If this happened, the state would have lost its voice in the particular presidential election. The political implications obviously would cause a hesitancy in Congress to exercise such power. The strict party lines upon which the 1876 Hayes-Tilden election was resolved in Congress is indicative of the extreme reluctance which a party in power would hold towards rejecting electoral votes cast for its candidate. Another historical lesson may lie in the fact that Congress never refused to seat members elected from congressional districts which did not conform to federal statutory requirements during the period from $184^{2}$ to 1929 when there was pertinent federal legislation on the books. Some point also to the fact that Congress has never exercised its power under the fourteenth amendment to reduce a state's representation in Congress because of denial of voting rights.

Another possibility is simply to allow Congress to establish the districts or to give it a corrective power to modify districts established initially by the states. Once again is reared the ugly head of party politics. If our present system has any particular advantage, it is the certainty and inflexibility of fifty electoral districts. It is known from one election to the next just exactly what the system will be throughout the entire country. The complexities and uncertainties of the district system would be a considerable departure from this.

The conceptual basis of the district system raises an interesting question of political theory. It is called the "counterpart system" by some because it would put the Presidency and the Congress on the same political base. People would vote in the same combinations and with the same relative weight for the Presidency as they do for their share of the total representation in Congress where each voter is represented by his state's two senators and the representative from his congressional district.

Many feel that this is desirable and that it would produce a President whose program and political beliefs are more likely to be in harmony with those of the Congress. After twenty-three years in Congress, I am inclined to doubt that there is any such "consensus" among 535 legislators which could or should be a yardstick for measuring the Presidency. A President who had to appeal separately to the myriad of conflicting state and district interests represented in Congress would be less likely to have the positive and dynamic program for action which is needed for that high office under the demands of the cold war and space age.

A strong argument can be made, too, that the Presidency and the Congress should not necessarily be responsive to exactly the same electorates. The separation of powers doctrine may require not only a division of powers between the separate branches, but also having them responsive to different electorates-that is, the people voting in different combinations. Having the President elected upon a different 
political base helps to insure that conflicting interests are all represented in the federal government and the interplay of the executive and legislative branches helps towards ultimate accommodation of the legitimate interests of all segments of our society. Along these general lines, James Madison wrote, ${ }^{19}$

It is of great importance in a republic not only to guard the society against the oppression of its rulers, but to guard one part of the society against the injustice of the other part. Different interests necessarily exist in different classes of citizens. If a majority be united by a common interest, the rights of the minority will be insecure. There are but two methods of providing against this evil: The one, by creating a will in the community independent of the majority-that is, of the society itself; the other, by comprehending in the society so many separate descriptions of citizens as will render an unjust combination of a majority of the whole very improbable, if not impracticable. ... The second method will be exemplified in the federal republic of the United States. Whilst all authority in it will be derived from and dependent on the society, the society itself will be broken into so many parts, interests, and classes of citizens, that the right of individuals, or of the minority, will be in little danger from interested combinations of the majority.

Also, the concept underlying the election and functioning of Congress breaks down when one attempts to transfer it to the Presidency. Unlike electoral votes, senators and representatives cannot be equated to each other. The 435 members of the House are coordinate with only Ioo senators. Yet no one suggests that the Ioo electors corresponding to senators should have a weight in the presidential election equal to that of the 435 electors corresponding to representatives.

In another sense, the district system would not be a counterpart of congressional elections in the constitutional sense. The Constitution left the states free, subject to ultimate congressional regulation, to elect their representatives either at large or by districts. The framers did not specify how either electors or representatives would be chosen. The district system would make presidential elections a constitutional counterpart of an extra-constitutional method of electing representatives. That the framers did not contemplate true counterparts is suggested by the fact that the Constitution protects each state from having its representation in the Senate taken away without its consent but makes no similar provision for the two presidential electors corresponding to senators.

The truth is of course that the constitutional schemes for both presidential elections and congressional representation were necessary compromises between large and small states to secure ratification. They were hammered out as matters of necessity along similar lines by giving equal representation to states in the Senate and two bonus electors to each state in the poorly conceived electoral college, but here the similarity ceases. I think the demands upon and duties of the Presidency are so vastly different from those of senators and representatives that it serves no purpose to seek further common constitutional bases in their election. If the district system were a true counterpart, it would be more cause for criticism than for support.

${ }^{10}$ The Federalist No. 5r, at 325-26 (Lodge ed. I888) (Madison). 


\section{The Proportional System}

Like the district system, this plan retains the states' electoral votes and seeks to eliminate the unit rule. Instead of using districts within states to split state units, it would divide every state's electoral votes among the candidates in proportion to their shares of its popular vote. Unlike the district system, it insures that the electoral votes of every state will be apportioned among the principal candidates, and it accomplishes this while still retaining the fifty states (and the District of Columbia) as the only separate electoral districts. This proposal is commonly called the "Lodge-Gossett" plan, for Senator Henry Cabot Lodge of Massachusetts and Representative Ed Gossett of Texas, who were its principal sponsors when it was approved by the Senate in 1950 by a vote of 65 to 27 . Electors are eliminated and each state's electoral votes are divided to the nearest one-thousandth in the same proportion as the total popular vote of the state. Forty per cent of the total number of electoral votes is necessary for election. In the event no candidate receives forty per cent, election is by the House and Senate in joint assembly with each member having one vote and a majority of the votes being necessary for election.

If I appear to have some slight prejudice in favor of this approach, it is because I have supported it for a number of years, both in the House and Senate. It seems to me to be the reform which best meets the principal evils of the present system while introducing a minimum of new complications or inequities. The idea is not of recent vintage, although not so old as the district system, having first been proposed as a constitutional amendment by Representative Lawrence of New York in 1848. In the 1870 's Representative Ashley of Ohio even advanced a proportional plan which retained the individual presidential electors. ${ }^{20}$

In 1896 , the classic essay of Dr. Herman V. Ames analyzed all proposed amendments to the Constitution of the United States during the first century of its history. Of those concerning presidential elections, he concluded that, ${ }^{21}$

The proposition for the distribution of the electoral vote of each state among the candidates in the proportion the electoral ratio shall bear to the popular vote of each candidate seems the fairest and most desirable of all the plans presented, as it retains the relative importance of each state, and at the same time secures to the minority its due proportion of the vote.

When the Senate approved the "Lodge-Gossett" plan by the lopsided 65 to 27 vote in I950, it was the first break-through for electoral reform in either house in 125 years. But the groundwork in the House had been poorly done. It was only con-

\footnotetext{
${ }^{20}$ The voters were to vote directly for President and Vice President and the legislature was then to appoint the electors, taking care to secure to each candidate voted for in the state an equitable representation in the electoral college, as indicated by the number of votes returned for each candidate. Hearings, supra note 2 , at $8 \times 6$.

${ }^{21}$ Id. at 804. This prize essay, "Proposed Amendments to the Constitution of the United States During the First Century of Its Fistory," was first published in 2 American Historical Ass'n, ANn. Rep. FOR THE YEAR I896 (I897); see id. at I 13.
} 
sidered under a motion to suspend the rules for its consideration and this was soundly defeated by a vote of 2 Io to 134 .

The proportional plan bounced back in 1955 when the Senate Judiciary Committee again reported it favorably. Before it was considered on the floor of the Senate, a compromise was reached to secure the support of those who favored the district plan and a substitute amendment was offered by the principal sponsors under which each state would be given the option of using the proportional system or the district system. The substitute amendment was only agreed to by a vote of 48 to 37 . This made it apparent that the requisite two-thirds approval could not be obtained and the principal sponsors moved to recommit the resolution to the Committee on the Judiciary. (This "neither fish nor fowl" hybrid proved more vulnerable in debate than either plan separately and it has not been seriously considered since. It has not even been reintroduced as an original resolution in the Senate.)

The proportional plan proved to be the most popular in the poll of political scientists which I mentioned earlier, drawing approval from 46.9 per cent as against only r6.2 per cent for the district system. Unless it has lost its steam from past reversals, it would still seem to be the most likely possibility for substantial reform. What are the objections to it?

The criticism most often made of the proportional system is that it would encourage splinter parties and endanger our two-party system. A splinter party could reflect its popular votes in the electoral college by polling small percentages of the popular vote within a state and could obtain roughly the same proportion of the national electoral votes as it obtains of the total popular vote.

Neither the assertion nor denial of this charge is susceptible of much proof or documentation. But the American voter characteristically wants a chance of voting with the winner. Whether his vote is counted out at the state or district level by a unit rule, or at the national level where it is insufficient by virtue of its total, he is not likely to waste his vote on a third party candidate who has no chance of winning.

The requirement of only a forty per cent plurality of the electoral votes for election is also a deterrent to third party movements. A third party could not expect to throw the election into Congress with less than twenty per cent of the total electoral vote. If an election is ever thrown into the Congress, the choice there is limited to the top two candidates (as against three under present constitutional provisions), which will prevent a third party candidate from being considered or holding the balance of power there.

Some criticize the forty per cent provision and call it a departure from traditional majority rule concepts and an implicit admission that candidates would be less likely to capture electoral majorities under the proportional system. But any elective system must provide in some way for an ultimate final choice, and any provision of this sort is at best a compromise. Election by the 535 individual members of Congress is generally regarded as the best contingent method but this is to be avoided if reasonable alternatives are available. I believe I speak for many members when I 
say that it is a function we would not relish. The forty per cent provision should cause elections in Congress to be very, very rare. Election of a candidate who has such a plurality is preferable to election by the Congress. This provision has much to commend it for any proposal.

The proportional system is often met by critics' cries of "proportional representation," or "P.R.," a system of representation which allows minority parties to elect delegates to parliamentary bodies. This term would certainly apply to the proportional plan if the electoral college were a deliberative body and individual electors were divided proportionally among all parties which polled popular votes. Any representation concept becomes irrelevant when the college of individual electors is eliminated. Electoral votes are retained only as a counting device for the federal purpose of weighting voting strengths among the various states. The object is to choose one Chief Executive for the nation, and as Senator Lodge stated in 1950: "Even the cleverest surgeon cannot divide one man up-proportionally or otherwiseand expect him to live." If this system involves proportional representation, then so do ninety-nine per cent of our elections in America because it only provides for counting all votes cast. Direct national election would do the same thing. Once it is recognized that "representation" is not involved and that "proportioning" is done so that our electoral counting device accurately projects the popular will of each state, then the proportional representation argument vanishes.

Indeed, dividing electoral votes to reflect the popular votes could minimize, rather than encourage, the influence of multiple parties and pressure factions. Small groups in large pivotal states now hold positions of great importance because they may add or withhold enough votes from either party to swing the state's entire block of electoral votes. Examples include the Liberal Party in New York and the candidacy of Henry Wallace in 1948, which is considered to have thrown two states to Mr. Dewey.

The district system may be equally or more vulnerable in this respect by its localizing effects. For instance, a Farm Party in agricultural sections, or a Labor Party in industrialized areas might capture enough single-elector districts to gain a balance of power position in the electoral vote.

In the 1956 Senate debates and again in our 196r Hearings, it was argued that the proportional system would penalize two-party states and favor the so-called oneparty states. One witness cited as an example that under the unit rule system, $\mathrm{Mr}$. Kennedy won the states of Connecticut, New York, New Jersey, and Pennsylvania in r 960 by a combined margin of 613,000 votes. He won Georgia and Louisiana by a combined margin of 360,000 votes. If the proportional plan had been in effect, he would have gained a margin of 3.835 electoral votes in the larger group of states and a margin of 5.196 in the latter two states. In other words, a popular margin of $6 \times 3,000$ in closely contested states would have netted less than three-quarters as 
much electoral vote advantage as a popular margin of only 360,000 in one-party states. $^{22}$

This analysis is directed only to the net advantage in each group of states. Under the proportional system, Kennedy would have captured a total of 52.267 electoral votes from the first group of states but only 12.546 electoral votes from the latter. ${ }^{23}$ Under any system, a candidate must obtain a majority (or at least forty per cent) of the entire electoral vote of the nation and will seek an aggregate of electoral votes as well as aggregates of "advantages." Kennedy's votes in the first four states would still have contributed four times as much to his election as the votes of the latter two states.

Let us look at how important New York would still continue to be as a state. Under the proportional plan, Mr. Kennedy would have received 23.638 of New York's forty-five electoral votes in 1960 , more than his combined share of the total electoral votes of Arkansas, Georgia, North Carolina, and South Carolina, where he would have won 22.9II of forty-two electoral votes. Under the proportional plan, one-half of New York's electoral votes is still greater than the combined electoral votes of seven states and would be eleven per cent of the total necessary for election. ${ }^{24}$

Where the district system fragments New York's electoral vote into forty-five pieces, the proportional system still allows each New Yorker's ballot to count towards the state's entire block of electoral votes-but only in proportion to relative party strengths within the state. By contrast to the unit-rule system, each party's weight in the national totals would only be in accordance with the relative weights in the state popular vote. Since this same principle would apply to all states, New York would have the relative voice to which its electoral vote entitles it, but no more.

A similar argument has caused many Republicans to look upon the proportional plan with disfavor. It has been shown that in most past elections Democratic candidates would have profited from the proportional system because of the so-called "Solid South."25 Democratic candidates would have given up fewer electoral votes by proportional division in southern states than they would have gained by proportioning the more closely contested northern and western states. ${ }^{26}$

${ }^{22}$ Statement submitted by Gus Tyler, Director, Political Department, International Ladies' Garment Workers' Union, in Hearings, stipra note 2 , at 672.

${ }^{2 B} \mathrm{Id}$. at $\mathrm{AII}$.

24 Ibid.

${ }^{26}$ See speech by Senator Paul H. Douglas on Senate floor, March 26, 1956, in Hearings, supra note 2, at 744-76, and statement of Professor Ruth C. Silva, in Hearings Before a Subcommittee of the Senate Judiciary Committee on Nomination and Election of President and Vice President, 84th Cong., Ist Sess. 334 (1955).

${ }_{20}$ The most frequently cited example is the election of I900, when William McKinley had a total popular vote of $7,219,000$ or 52.8 per cent, and William Jennings Bryan had a popular vote of $6,358,000$ or 47.2 per cent. McKinley won with 292 electoral votes to Bryan's 155 . If the proportional system had been used, with the same popular vote figures, Bryan would have had 218 electoral votes and McKinley 214. Yet Bryan had carried only seventeen states, eleven of them in the South, two border states, and four Western states, while McKinley had carried twenty-eight states, including all the Eastern, Middle Western, and Pacific Coast states, three border states, and two Western states. In other words, under the proportional system, McKinley would have lost many more electoral votes outside the South because of Democratic minority votes than he would have gained by virtue of Republican minority votes in solid Democratic states. 
This objection is fast losing its validity. In the last four elections, there are only six states which have not gone Republican at least once ${ }^{27}$ and nine states have gone Republican every time. ${ }^{28}$ Having seen Tennessee go Republican in 1952, 1956, and I960, I am painfully aware that in presidential elections the two-party system seems to have arrived in the South. The Midwest is beginning to appear more solidly Republican than the South is Democratic. In any event, an argument based upon shifting patterns of sectional party strength should not control in evaluating the soundness of a constitutional system to be used over a long period..$^{29}$

Another objection often raised is that this plan would encourage disputed elections. In one sense, this is true. Any contest in any state which appreciably varied its popular vote totals would also vary the state and national electoral vote totals. Those seeking to change the apparent results of a close election could look anywhere in the country for a potential election contest. This would also be true under direct national election and shows that the proportional plan is a substantial movement in this direction. The district system's proliferation of election jurisdictions correspondingly increases the potential for contests but, like the proportional system, it reduces the effects of local irregularities.

The temptation to cry or commit fraud and to challenge election results will be much less when the shift of a handful of votes in a state can no longer tip inordinately great blocks of electoral votes from one column to another. Under the proportional system, the effect of accident or fraud in the electoral vote column would be only in proportion to its effect on the popular vote. Only in an extremely close election on the national scale would it be worth the trouble to contest local results. As Ig60 demonstrated, such an election will always bring uncertainty in determining the final results.

The mathematics involved in computing each state's electoral vote to the nearest one-thousandth also troubles some observers. But when it is considered that roo popular votes may be represented by one-thousandth of an electoral vote, this becomes a positive advantage. Again it illustrates that, except for retaining the electoral vote weighting of states' votes, the proportional system amounts to direct election.

Both the district and proportional systems would alleviate the great emphasis now placed upon the large pivotal states and relatively small organized groups of "swing voters" who may hold the balance of power in such states. The district system largely isolates voters' influence to the districts where they live and the proportional system limits their voice to its proportionate numerical weight. Under

${ }^{27}$ Alabama, Arkansas, Georgia, Louisiana, Mississippi, North Carolina, and South Carolina. (Four of these went to the States' Rights candidates rather than Democratic in r948.)

${ }^{28}$ Indiana, Kansas, Maine, Nebraska, New Hampshire, North Dakota, Oregon, South Dakota, and Vermont.

${ }^{29}$ Although I think it can be highly misleading to rely upon hypothetical studies of past elections, the 1960 figures should be considered against those which have been used to argue that the proportional plan favors Democrats. The Congressional Quarterly's compilation of the 1960 results shows that Nixon would have won by less than one half of one electoral vote under the proportional system. Hearings, supra note 2, at $4 \mathrm{Ir}$. (This requires a division of the Alabama Democratic vote $5 / 1 \mathrm{r}$ to Kennedy and $6 / I I$ to unpledged, which gives Nixon a 1.750 electoral vote margin in Alabama.) 
either system, campaigns would be directed more to the country as a whole. Citizens of smaller states are now less apt to see the candidates in person and they understandably may feel that their interests are of lesser importance to their President. Except for Alf Landon of Kansas in 1936 and the incumbent President Truman of Missouri in 1948 , both major parties have limited their presidential nominations in the last halfcentury to men from the eight largest states. Able men from small states now have little chance to secure nominations from either major party and are seldom even regarded as presidential timber.

Elimination of the unit rule by either the district or proportional system would thus go far towards truly "nationalizing" our presidential elections by restoring some balance to the roles of citizens in different sections of the country. The proportional system, however, would be less apt to swing the pendulum too far. The electoral votes of a large state would still be sought as a unit even though they are to be apportioned later in the counting process. The district system would partition large states' voters into small units and leave only two electors as the target of statewide efforts. Considering the small fraction which the two at-large electors account for in most states' electoral votes, it is safe to say that the state as such would become insignificant as an election unit. Real damage to our federal principles could result if parties and candidates become unconcerned with state interests. Continuing the state unit system to the extent the proportional system does is not only a fair price to pay for keeping the electoral vote advantage of small states, but is also good insurance that presidential elections will retain a sound balance between local, state, and national interests.

\section{ELIMINATION OF ELECTORS}

Doing away with the troublesome institution of individual presidential electors is a procedural reform which could be accomplished with or without other substantial reform and without touching the balance of political power in the country. One may well wonder why this was not done long ago apart from other controversies about the system.

This idea is almost as old as the electoral college itself. As soon as the rise of the two-party system and popular democracy caused electors to become mere "dummies," proposed amendments in the Congress began to include or center upon provisions for abolition of the office of elector. A Senate Committee headed by Senator Thomas Hart Benton in 1826 recommended a form of the district system under which people would vote directly for President without the intervention of electors. Its report stated $:^{30}$

In the first election held under the Constitution, the people looked beyond these agents, fixed upon their candidates for President and Vice President, and took pledges from the electoral candidates to obey their will. In every subsequent election the same thing has been done. Electors, therefore, have not answered the design of their institution.

${ }^{30}$ Senate Select Comm., Resolutions Proposing Amendments to the Constitution of the United States, S. Rep. No. 22, 19th Cong., Ist Sess. 4 (1826). 
They are not the independent body and superior characters which they were intended to be. They are not left to the exercise of their own judgment; on the contrary, they give their vote, or bind themselves to give it, according to the will of their constituents. They have degenerated into mere agents, in a case which requires no agency, and where the agent must be useless, if he is faithful, and dangerous if he is not.

Also in 1826 , Representative Haynes of Georgia was introducing the first proposed amendment to abolish electors and automatically award a state's entire electoral vote to the winner of its popular vote. At the same time, the legislators of Georgia, Alabama, and Missouri concurred in resolutions proposing amendments along the same line.

President Andrew Jackson, in his first annual message to Congress, urged that the people within the states should vote directly for the President, warning that "in proportion as agents to execute the will of the people are multiplied, there is danger of their wishes being frustrated. Some may be unfaithful, all are liable to err."31 Andrew Johnson, as Representative, Senator, and President, advocated direct election by districts without electors, as did Senator Oliver P. Morton, of Indiana, the leading advocate of electoral reform in the I870's. In 1934 an amendment abolishing electors sponsored by Senator Norris of Nebraska passed the Senate $5^{2}$ to 29 , just short of the required two-thirds approval.

Concern with the constitutional independence of electors is considered trivial by some. From $x 789$ to 1960 , in no more than eight instances of a possible 14,000 can it be said that individual electors departed from their mandates, and none of these affected the result of an election. However, three of these eight instances have occurred since r 948 and there is current evidence of substantial efforts to control election results by exploiting the elector's constitutional independence.

A I948 Tennessee elector who was on both the Democratic and States' Rights tickets was elected as a result of popular votes cast for the Democratic ticket. Nevertheless, he voted in the electoral college for the States' Rights candidate. Although he had indicated his intentions before he was elected, his presence on the Democratic ticket of electors made it impossible for the voters of Tennessee to register the state's entire vote for the Democratic nominee. In 1956, one Alabama Democratic elector voted for a person other than the Democratic nominee. In ig60, Mr. Henry D. Irwin, a Republican elector from the state of Oklahoma, cast his vote for Senator Harry F. Byrd instead of Mr. Richard Nixon.

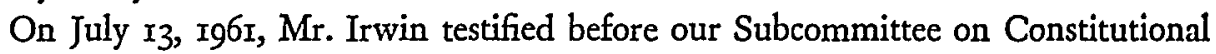
Amendments concerning his actions. ${ }^{32}$ Without opposition in the Republican primary, he had been one of eleven electors nominated by the Oklahoma Republican Party. In order to qualify for the primary, he had been required to file a sworn written statement that he believed in the principles of the Republican Party and intended to vote for its nominees at the coming general election. (Since the electors,

\footnotetext{
${ }^{31}$ Message to Congress, Dec. 8,1829 , in Andrew Jackson, Annual Messages to (Coale \& Co., 2d ed. 1835 ).

${ }^{32}$ Hearings, supra note 2, at 562-655.
} 
and not Nixon and Lodge, were the nominees of the Republican Party in the general election, Mr. Irwin technically carried out this pledge by voting for himself and the other Republican nominees for elector.) Mr. Irwin testified that he never intended to vote for Nixon if he were the nominee. ${ }^{33}$

When the Republican ticket carried Oklahoma by over 160,000 votes, Mr. Irwin was elected to the exalted constitutional office of "elector of the President and Vice President." Irwin then helped spearhead an almost unbelievable "coalition movement" between the general election and the meeting of the College of Electors on December 19. It sought to combine Republican electors who would otherwise have cast useless votes for the defeated Mr. Nixon, with enough unpledged and defecting Southern Democratic electors to elect some third candidate in the electoral college.

Mr. R. Lea Harris, an attorney of Montgomery, Alabama, conceived the idea and wrote to all presidential electors on November 9 of plans for such a coalition. Irwin was attracted to Harris' idea and agreed to solicit all Republican electors for the plan. Irwin wired every elected Republican elector in the country urging them to join the coalition and vote for a third ticket. He received approximately forty responses from Republican electors. The great majority indicated a feeling of legal or moral obligation to vote for Nixon. About thirteen indicated interest in the coalition plan and a desire to participate if it had any chance of success. Three were interested if they were released from pledges by official party organizations.

Irwin then decided that the principal obstacle to the coalition was the "false assumption" by electors that they were obligated to vote for Nixon. He then wired each Republican National Committeeman and each State Republican Chairman and urged them to release the Republican electors from any feeling of moral obligation to vote for Nixon so they could join the coalition. He received six responses, three of which were sympathetic but none offering assistance. The high point of Irwin's effort was the New Mexico Committeeman's response that he had taken up the matter with party leaders at "the Republican National Committee level," and that although they favored the move, they felt it should not be sponsored by the party organization. ${ }^{34}$

Irwin and Harris bombarded electors with literature urging them to cast "free votes" as their constitutional right and duty, but on December I9, all Republican electors except Irwin himself stood firm and voted for Nixon. Along with the fourteen unpledged electors of Alabama and Mississippi, Irwin voted for Senator Byrd.

Harris and Irwin concluded that his vote had served to educate people to the freedom of electors and immediately started working towards rg64. In a postmortem form letter of December 30 , 1960 , Harris laid out plans for a similar effort for Ig64 and urged "friends of the movement" to begin now to arrange to become presidential electors. $^{\mathbf{3 5}}$

As a result of Irwin's actions, Oklahoma election laws were amended in I96I to

${ }^{\text {as }}$ Id. at 598-99.

${ }^{34}$ Id. at 617 .

${ }^{35} \mathrm{Id}$. at 607 . 
provide that electors shall be chosen by state party conventions, that each must sign an affidavit that he will vote for the party nominee, and that violation of the oath is a misdemeanor punishable by $\$ \mathrm{r}, 000$ fine. ${ }^{36}$ The fine is the only means of enforcing the oath. If an elector is willing to incur the fine or wishes to contest the constitutionality of the law, he could still vote for someone else and his vote would be so recorded. Mr. Irwin testified that the prospect of such a fine would not have deterred him if there had been such a law in Oklahoma in $x g 60$.

In the emotionally-charged climate of presidential elections, circumstances are not at all inconceivable where enough electors might follow Irwin's example to change the result of an election. Considering the excess-baggage nature of the elector, why should any risk be taken that a few individuals could some day miscarry an election when they have long since ceased to serve their intended purpose and are at best an imperfect conduit?

It is too bad the elector cannot be eliminated by a constitutional amendment which said nothing more, but this is not possible. Any amendment which eliminates the elector but retains the states' electoral votes must include some means for translating popular vote pluralities into electoral votes.

The minimal amendment would seem to be one which provides that the state's electoral vote will be automatically awarded to the winner of its popular vote as has been the virtually uniform practice for 135 years. In much the same manner as electors' votes are now certified to the Congress, the vote of the people for the candidates could be certified directly. Ample time could still be allowed for resolving election contests at the state level before certification of results. In fact, more time could be allowed and the possibility of resolving disputes in the Congress could be reduced because of the elimination of the intermediate step of electors meeting and voting.

This straightforward proposal meets opposition from two sources. One school of thought resists incorporating the unit-rule system in the Constitution. They feel that this might freeze this system for a number of years and harm the chances for more substantial reform. I doubt this. The public's view of such an amendment would be that it was directed simply at the office of presidential elector and not at any broader problem. In any event, this improvement is sufficiently worthwhile of itself to justify the slight risk of hampering further reform.

A second source of opposition is the few who believe the presidential elector to be a worthwhile office which ought to be retained. These are not merely the tiny number of extremists who want the elector to exercise his independent judgment and choose the President. Some few believe the elector is essential to preserving state control and decentralization of presidential elections. ${ }^{37}$

I have considered this argument carefully but cannot agree. Just as state law and the two-party system are now trusted to produce elections of presidential electors, they can also be trusted to produce elections of presidential candidates. A corrective

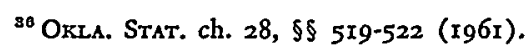

37 American Good Government Society, How Should the President be Elected? 12 (196r). 
amendment of the type I have mentioned would simply guarantee to the people of each state the right to vote directly for the President, just as they now do for congressmen and senators. Voting qualifications for presidential elections could also be left expressly to state control as could regulation of the times, places, and manner of elections. The nominating process is now extra-constitutional and would continue to be so. Just as state law now determines how electors get on the ballot, state law could as easily prescribe how the names of presidential candidates get on the ballot. In thirty-three states which have so-called "short ballots," it is the names of presidential candidates, not the electors, that now appear on the ballot.

If he functions as expected, the elector is only a conduit through which the popular will is conducted and a more reliable conduit is readily available. The popular vote of each state can be transformed directly into the electoral vote counting process. We now have four steps: (I) The people elect electors in November; (2) the electors meet and elect the President in December; (3) the states certify the electors' votes to Congress; and (4) the Congress counts and certifies the final result in January. This proposal simply eliminates the second step and requires the states to certify their popular vote totals to Congress where it is simple arithmetic to count the electoral votes accordingly. Legally and constitutionally, we do not have a President-elect until December. If the electors were eliminated, we would have a President-elect in November.

Should the elector be retained for the possible exercise of his constitutional discretion in this interim? There is no conceivable situation where the elector might exercise his discretion which could not be handled better in some other way. If the successful candidate dies between the November election and December electoral college meeting, party regulations and state law now provide methods which direct the elector how to vote. Once the electors meet and vote, we now have the same situation until Congress convenes as we would have without electors from the popular election until Congress meets. No new problem or vacuum would be created.

Elimination of electors would also eliminate the use of unpledged electors as occurred in two states in 1960 . In a sense, this was a return to the system contemplated by Hamilton and the Founding Fathers; but almost everyone today believes that the American people should elect their President. More important, unpledged electors should be precluded because of their potential for manipulation and balanceof-power bargaining in a close election.

An amendment which abolished electors could also improve the present provision for contingent elections in the House of Representatives. If the electoral vote fails to produce a majority for any candidate, the Constitution now places the election in the House of Representatives with the delegation of each state having one vote. In 1800 and 1824 our Presidents were elected in this manner. Since each state's vote is determined by the majority of its delegation, if a delegation is evenly split, the state would lose its vote. It is also unfair to give a one-member state delegation ${ }^{38}$ the same voice as the forty-one member delegation of New York. The opportunity for

${ }^{8 B}$ Alaska, Delaware, Nevada, Vermont, and Wyoming each have one representative. 
deadlock and third party balance of power is also apparent. Most proposed amendments would correct this inequity by substituting election by a joint session of the House and Senate with each member having one vote. This would give each state the same relative weight that it has in the electoral vote.

Indications are that the House would not object to sharing this responsibility with the Senate. In fact, after the Adams-Jackson-Crawford deadlock of $1824,{ }^{30}$ the House adopted a resolution urging that some provision be made so that election of the President could never again devolve upon the Congress.

An amendment aimed at electors and contingent elections which accepted the unit rule would at least perfect the present system as it is generally expected to function. It would provide a certain and uniform system which could not be manipulated from state to state or from election to election. In urging such an amendment, one scholar calls it a "housekeeping amendment." ${ }^{\text {"No }}$ This approach was supported by President Kennedy as a Senator ${ }^{41}$ and by the Department of Justice in our I96r Hearings. ${ }^{42}$ It has also been endorsed by an influential bar association. ${ }^{48}$ This amendment would at least put our present electoral house in order while we continue the debate of whether to rebuild its basic structure.

\section{Conclusion}

I would not attempt to predict which of the possible reforms may become law or when this may occur. It has been $15^{8}$ years since the constitutional method of electing the President was touched in any respect and it would be most presumptuous to make specific claims for the future. However, I do believe the climate for electoral reform is improving perceptively and that some of the most serious past obstacles are being removed.

Division among proponents of reform should lessen as a result of the current consideration of the subject by the public and in the Congress. ${ }^{44}$ There will probably be lessened efforts for proposals which are shown to have no chance of success and their supporters will then be faced with a choice between the status quo and some other proposal. Through a process of narrowing the alternatives one of the basic proposed reforms should emerge as the only realistic alternative to the present system. What are now four or five opposing camps will become but two. When this occurs, but not before, I believe we can expect something substantial to be done.

\footnotetext{
${ }^{80}$ Heniry Clay was third in the popular vote but had fewer electoral votes than Crawford. Since the choice in the House was limited to the top three, Clay was not included.

${ }^{10}$ Burns, A New Course for the Electoral College, N.Y. Times, Dec. 18, 1960 (Magazine), p. 10, cols. I-4.

32 S.J. Res. 132, 85th Cong., Ist Sess. (1957).

${ }^{22}$ See testimony of Nicholas deB. Katzenbach, Assistant Attorney General, in Hearings, supra note 2, at $37 \mathrm{I}$.

${ }^{4}$ Resolution of the Bar Association of the City of New York, Jan. 16, 1962.

"After this article was written, the Senate Judiciary Subcommittee on Constitutional Amendments, by a 4 to 2 vote, favorably reported S.J. Res. 12 (the district system) with amendments to the full Judiciary Committee on May 2r, 1962 . The subcommittee amendments would require pledges of electors and invalidate electoral votes cast in violation of such pledges.
} 